\title{
Cash Reserve Ratio and Credit to Micro-, Small and Medium-Sized Enterprises in Developing Economies. Analysis of Transmission Channels Using Nigerian Data
}

\author{
Anthony Orji ${ }^{1}$, Christian E. Ugwu' ${ }^{2}$, Jonathan E. Ogbuabor ${ }^{3}$, \\ Onyinye I. Anthony-Orji ${ }^{4}$, Lynda C. Nwufo ${ }^{5}$ \\ 1-5 University of Nigeria, Department of Economics, Nsukka 400001, Nigeria \\ ${ }^{1}$ anthony.orji@unn.edu.ng \\ 2 ugwuchristian68@yahoo.com \\ 3 jonathan.ogbuabor@unn.edu.ng \\ ${ }^{4}$ onyinye.anthony-orji@unn.edu.ng (corresponding author) \\ ${ }^{5}$ lynda.nwufo@unn.edu.ng
}

\begin{abstract}
This study examines the channels of transmission through which cash reserve ratio impacts on credit to micro-, small and medium-sized enterprises (MSMEs). A vector error correction model was used to capture the objective. Quarterly data ranging from 2001 to 2017 were also utilized in the analysis. The study found that cash reserve ratio indirectly impacts credit to MSMEs through liquidity ratio and lending interest rate as its channels of transmission. It is worthy to note that, as liquidity ratio has a positive significant impact on credit to MSMEs, lending interest rate has a negative but significant impact on credit to MSMEs. To boost economic productivity in developing economies, the study therefore recommends that the monetary authorities reduce the cash reserve ratio in order to increase commercial banks' liquidity. As the commercial banks' liquidity rises, they should also reduce their lending interest rate to increase access to credit by MSMEs. Again, the government should appropriate and monitor the judicious disbursement of interest-free loans/credit to MSMEs through banks, especially development banks.
\end{abstract}

Keywords: cash reserve ratio; credit; channels of transmission; micro-, small and medium-sized enterprises

JEL: E51, G21, L26

For citation: Orji A., Ogbuabor J.E., Ugwu C.E., Anthony-Orji O.I., Nwufo L.C. Cash Reserve Ratio and Credit to Micro-, Small and Medium-Sized Enterprises in Developing Economies. Analysis of Transmission Channels Using Nigerian Data. Financial Journal, 2022, vol. 14, no. 1, pp. 71-88.

https://doi.org/10.31107/2075-1990-2022-1-71-88.

(c) Orji A., Ogbuabor J.E., Ugwu C.E., Anthony-Orji O.I., Nwufo L.C., 2022 


\section{INTRODUCTION}

Globally, there is a growing recognition of the important role that micro-, small and mediumsized enterprises (MSMEs) play in economic development [Nwosu E.O. et al. 2020; Orji A. et al., 2019]. They play a crucial role through several dimensions, apart from creating employment opportunities. They not only contribute significantly to improving the living standards of the larger population, but also create a platform for local capital formation, innovation and competition in Third World countries.

According to the Nigeria Bureau of Statistics, the 2013 National MSME Survey, which was conducted in all the 36 States of the Federation and the Federal Capital Territory, Abuja, revealed that the total number of MSMEs as at 2013 was about 37,067,416 (micro, 36,994,578; small, 68,168; and medium, 4,670). In addition, the total number of persons employed by the MSME sector as at December, 2013 was about 59,741,211, representing $84.02 \%$ of the total labor force in Nigeria and contributing $48.47 \%$ to the Nation's Gross Domestic Product in nominal terms.

However, amongst the six main challenges confronting the operations of MSMEs in Nigeria as revealed by the survey are access to finance and poor infrastructure, inconsistency in government policies, poor support (business development services), access to market, multiple taxation, and obsolete technology. The most challenging of all is access to credit [Nwosu E.O., Orji A., 2016]. Thus, this paper investigates the channel of transmission of cash reserve requirement in widening access to credit for MSMEs.

The Central Bank of Nigeria (CBN) Monetary Policy Circular No. 22 of 1996 defines a small or medium business enterprise as any manufacturing or service enterprise whose business turnover does not exceed $\$ 500,000$ (including land and working capital) and whose annual turnover does not exceed $\$ 5$ million. In the 1990 budget, the Federal Government of Nigeria also defined small/medium-sized enterprises, for the purpose of commercial bank loans, as enterprises with annual turnover not exceeding $\$ 500,000$, and for merchant bank loans, as enterprises with capital investments not exceeding million excluding cost of land, with between 11 and 100 people employed. Large scale industries are those with investments of over $\$ 200$ million, excluding land but including working capital, and a workforce of over 300 people. According to Lawrence E. Imoughele and Mohammed Ismaila, the definition and criteria for classification of an enterprise as small, medium or large varies from one country to another, depending on whether it is a developed or developing country [Imoughele L.E., Ismaila M., 2014]. What constitutes an SME is a matter that each country decides individually as there is no universally accepted definition of what they are, as shown by the Central Bank of Nigeria's communiqué No. 69 (2010) of the special monetary policy committee which acknowledged the existence of several definitions of MSMEs. What is termed a large scale business in a developing country may be a small business to a developed one.

The Nigerian government has put in place several measures to promote the growth and development of MSMEs in terms of funds availability. The government has also collaborated with bilateral and multilateral agencies and non-governmental organizations (NGOs) in supporting MSMEs in Nigeria. The Federal Government of Nigeria negotiated and obtained the World Bank SME I loan scheme to the tune of US\$42 million in 1984. After the adoption of the Structural Adjustment Program (SAP) in mid-1986, the government again obtained the World Bank SME II loan scheme of US $\$ 270$ million for the development of MSMEs. However, the loan was reduced to US\$142 million in 1992. The scheme was said to have generated jobs for over 40,000 people at the end of disbursement in 1996 [CBN, 2000].

The Ioan was managed by the Central Bank of Nigeria and disbursed through a number of participating banks comprising of commercial, merchant and development banks. Despite the laudable schemes and institutions established like Small Scale Industries Credit Scheme, Peoples Bank Scheme, Community Banks Scheme, Nigerian Industrial Development 
Bank (NIDB), Nigerian Agricultural and Cooperative Bank (NACB), and National Economic Reconstruction Fund (NERFUND), among others, by the Federal Government of Nigeria from the inception of SAP to provide resources for the development of MSMEs, there is still shortage of funds either to begin or to expand existing MSMEs [Orji A., 2012]. Though some of the MSMEs are creditworthy to attract loans, the high risk associated with the MSME subsector normally serves as an impediment. Most operators of MSMEs live in their own houses in rural communities or in rented properties in towns. Houses or estates in rural areas may not qualify for acceptance as collateral security [Iniodu P.U. and Udomesict C.U., 2004]. Claims recovery and collateral realization are often very weak.

The barrier to credit protection is aggravated by the fact that the issuance of titles is extremely slow due to the absence of appropriate procedures for registration of properties and inadequate resources of property registration offices. Credit recovery is hampered by the malfunctioning and cumbersome legal and judicial procedures [Sacerdoti E., 2005]. The Agricultural Credit Guarantee Scheme Fund (ACGSF) was created to reposition the MSMEs by having access to funds, and also the government initiated a partnership with well-established financial institutions to provide financial and technical services to MSMEs through a well-developed investment scheme known as Small and Medium Industries Equity Investment Scheme (SMIEIS), which was launched in 2001. The scheme requires all banks to set aside ten (10) percent of their profit after tax (PAT) for equity investment and promotion of MSMEs. The total amount set aside for the scheme as at December 2005 amounted to N40.7 billion [CBN, 2005].

This study on cash reserve ratio (CRR), its transmission channels and credit to MSMEs in Nigeria is an offshoot of the discourse on the impact that credit in general has on MSMEs. Over time, scholars have attempted studying the impact of credit and the extent of its impact, but this study takes an in-depth analysis at a major causative influence of credit availability as contained in the monetary policies vis-à-vis cash reserve ratio of the monetary authorities. The study goes further to track and examine the transmission mechanism of CRR adjustment impulses on lending to MSMEs through the interest rate and liquidity channels.

The study would significantly inform decisions made by the monetary authorities on the influence of policies specifically with regards to MSMEs. It would guide them in mapping out a monetary policy mix in other to achieve a target, specifically, increasing credit to MSMEs. This study is also expected to help entrepreneurs understand and evaluate the relationship between some monetary policy variables such as CRR, interbank call rate, etc. and banks' lending behavior as this has a way of impacting the availability and accessibility of loanable funds to MSMEs in the economy. Entrepreneurs would also be beneficiaries of the findings of the study in that they would formulate informed decisions on the accrual of working capital for their businesses. Commercial banks that are primary sources of funds would be better guided in understanding the ripple effect that MSMEs' activities have on macroeconomic gains. As part of financial intermediaries who transfer funds from areas of surplus to areas of deficit, commercial banks would recognize why they should have their short-term liabilities fully covered by cash so as to avoid having a liquidity problem. Commercial banks would also be properly guided in terms of deciding on their lending rates, deposit rates and interbank call rates.

This study would be beneficial to other non-bank financial institutions whose services provide soft funds for MSMEs, as the study reveals the transmission mechanism of CRR impulses and their influences over funding of MSMEs in Nigeria. More so, this study would also highlight other economic fundamentals which might have a significant effect on credit to MSMEs. This would also be relevant to major stakeholders in the MSMEs environment as well as other researchers who may wish to delve into this topic in the course of time. This work is going to be highly resourceful to researchers as it would be a reference point for many. 
This paper is segmented into four different sections. Section 2 shows the review of relevant literature, while Section 3 focuses on the methodology and the empirical analysis. Section 4 contains the summary and conclusion.

\section{LITERATURE REVIEW}

\section{Theoretical Literature}

The theory underpinning this study is the supply leading theory of credit. This theory postulates that the existence of financial institutions like deposit money bank and the supply of their financial assets, liabilities and related financial services in advance of demand for them would provide efficient allocation of resources from surplus units to deficit units, thereby leading the other economic sectors in their growth process [Uzonwanne M.C., 2015]. This theory is said to perform in a way of promoting and stimulating entrepreneurial response in the modern sector.

The proponents of this theory believe that the activities of financial institutions serve as a useful tool for increasing the productive capacity of MSMEs in the economy. They opine that countries with better developed financial systems tend to grow faster in this aspect. This theory also provides a valid linkage between the banking sector liquidity, which is most likely affected by monetary policy, and MSMEs.

\section{Empirical Literature Review}

There are a plethora of studies that have investigated the relationship between credit to the private sector and other macroeconomic variables (see, for example, [Orji A. et al., 2015; Nwosu E.O., Orji A., 2016; Orji A. et al., 2019; Chinanuife E. et al., 2019], among others). However, none of these studies investigate the transmission channels through which cash reserve ratios impact on access to credit. In their own study, Theresa U. Anigbogu and colleagues investigated the effect of financial intermediation on small and medium enterprises' performance in Nigeria using the ordinary least squares (OLS) econometric model [Anigbodu T.U., 2015]. The findings revealed that, with the exception of bank interest rate to SMEs, all other variables - financial intermediation, commercial bank loans and advances to SMEs, bank lending rate to SMEs, exchange rate, and monetary policy - have a positive and significant influence on small and medium enterprises' performance in Nigeria. Also, Michaelo O. Ndugbu and Peter A. Okere investigated the impact of monetary policy on the performance of deposit money banks in the Nigerian economy (1993-2013) [Ndugbu M.O., Okere P.A., 2015]. Ordinary least squares method was used to analyze the data. The findings revealed that bank deposit rate has a significant inverse relationship with total deposit mobilized by all deposit money banks. These findings did not account for a verification of the long-run possibility of the relationship; thus, inferences might be subject to criticisms.

Maria C. Uzonwanne did a study on "deposit money banks and financing of small and medium scale enterprises in Nigeria" in the period 1995-2012 [Uzonwanne M.C., 2015]. Data used were collected from the Statistical Bulletin of the Central Bank of Nigeria. The paper employed the descriptive method. The findings revealed that deposit money banks in Nigeria have been lacking in this aspect. The study's non-use of empirical strategies creates oversight in the structural behavior of the data. Again their stationarity and reliability of influence were not observed. These create limitations to the findings of the study by Uzonwanne [Uzonwanne M.C., 2015]. In another study, Abiodun R. Ayeni-Agbaje and Augustine E. Osho examined the role of commercial banks in financing small scale enterprises in Ado Ekiti, Ekiti State [Ayeni-Agbaje A.R., Osho A.E., 2015]. The primary purpose of their study was to find out how SMEs can be developed through the intervention of the banking sector. Questionnaires were used as an instrument of primary data collection. Purposive sampling technique was used to select the sample; correlation analysis was employed using chi-square (x2). Findings 
revealed that there is a positive correlation between loan grants by banks and the growth and development of SMEs in Ekiti State. The authors though did not account for the significance of the correlation coefficient even as a positive correlation was found. Further, Jude A. Mbanasor and colleagues examined the influence of monetary policy variables on banks' credit supply to small and medium-sized enterprises (SMEs) in Nigeria [Mbanasor J.A. et al., 2015]. Time series data which were collected on a quarterly basis were elicited from the Central Bank of Nigeria Statistical Bulletin and financial statements for five deposit money banks. The data covered a period of 1995-2010 and were analyzed using fully modified least squares (FMOLS). The result of the FMOLS indicated that policies on interest rate and liquidity ratio were negatively and positively significant at 1 percent probability level respectively.

In an earlier study, M.A.Y. Rahji, and T.G.G. Apata, attempted deciphering the credit supply decisions of banks under the Small and Medium Enterprises Equity Investment Scheme in Nigeria [Rahji M.A.Y., Apata T.G.G., 2012]. The study adopted the tobit model in the analysis of cross-sectional data collected from lending banks' staff. The findings of this analysis may be misleading considering that credit supply to SMEs may not respond to short-run interest rate changes based on cross-sectional data but on long-run changes and time series approach. Another study conducted within that period [Ajayi F., Atanda A., 2012] analyzed the effects of monetary policy instruments on banks' lending disposition. The Engle-Granger two step co-integration approach was adopted based on the regression model that regresses banks total loan and advances on minimum policy rate, cash reserves ratio, liquidity ratio, inflation, and exchange rate. The empirical estimates indicated that bank rate, inflation rate and exchange rate are total credit enhancing, while liquidity ratio and cash reserves ratio exert a negative effect on banks total credit. Imoughele and Ismaila employed co-integration and error correction modeling (ECM) techniques to investigate empirically the impact of commercial bank credit on Nigeria's small and medium-sized enterprises between 1986 and 2012 [Imoughele L.E., Ismaila M., 2014]. The results revealed that savings time deposit and exchange rate have a significant impact on SMEs' output in Nigeria. Furthermore, commercial bank credit to SMEs, total government expenditure and bank density have a direct but insignificant impact on the country's SME output. The study also showed that interest rate has an adverse effect on SME output.

Mohammed Omika examined the necessity and strategies of re-positioning commercial banks in order to enhance the productive capacities of small and medium-sized enterprises [Omika M., 2014]. The ordinary least squares method was used. The results showed that there is co-integration between repositioning of commercial banks and capacities of SMEs to deliver products/services and there is significant dispersion resulting from lending conditions and macroeconomic variables. Felicia O. Olukoyo also investigated the determinants of commercial banks' lending behavior in Nigeria employing multiple regression analysis [Olukoyo F.O., 2011]. The study suggests that minimum cash reserve ratio has a positive functional relationship with commercial banks loans and advances. This indicates that stipulated cash reserve requirement ratio of commercial banks may not necessarily translate into poor lending performance or lower proportion of commercial banks' funds available for lending, respectively. Adijat M. Safiriyu and Bibiana O. Njogo employed primary data instruments to study the impact of micro-, small and medium-sized enterprises on employment generation in Lagos State, Nigeria [Safiriyu A.M., Njogo B.O., 2012]. The results of simple percentages and chi-square tests conducted show that micro-, small and medium-sized enterprises and sustainable development of Nigerian economy are positively related, just as promotion of MSMEs and improvements in employment generation are positively related and significant. Availability of finance has been widely viewed as a constraint to the growth of MSMEs.

Christian Glocker and Pascal Towbin investigated the circumstances under which cash reserve requirements are an appropriate policy tool for price or financial stability [Glocker $\mathrm{C}$., 
Towbin P., 2012]. The study assumed a small open economy model with sticky prices, financial frictions, and a banking sector that is subject to legal reserve requirement rules. It found that, contrary to a conventional interest rate policy, CRRs are more effective when there is foreign currency debt. Employing commentary and inductive reasoning, Obokoh L. Ogechukwu, Anthony E. Akinlo and Geoff A. Goldman draw evidence to examine the various schemes implemented by the Nigerian government through the CBN to alleviate the challenges of access to finance by SMEs in Nigeria [Ogechukwu O.L. et al., 2015]. Evidence suggested that most SMEs still struggle with access to finance as they face banks' stringent conditions as obstacles to loans as well as high rates of interest by deposit money banks. The study also showed that the special institution set by the government as a result of the schemes to help finance the SME sector appears to have performed below expectation due to inadequate funding, misallocation of limited resources, poor staffing and overlapping functions of the institutions.

Adedayo O.E. and Ayodeji E.A. examined the effect of cash reserve requirement on banks' lending to MSMEs in Nigeria. Data for the study were obtained from the audited annual reports of the selected banks in Nigeria [Adedayo O.E., Ayodeji E.A., 2015]. The results of the regression analysis conducted reveal that there is no significant relationship between cash reserve requirement and volume of loans that Deposit Money Institutions (DMIs) provide to MSMEs. A study by Martina Lawless and Fergal McCann examined the evolution of loan performance throughout the period of economic and financial crisis employing unique Irish MSMEs loan-level data, complete with quarterly loan ratings assigned by the lending institution over a period of three years, 2008-2010 [Lawless M., McCann F., 2012]. Through estimations with panel data, changes in employment across sectors are shown to be the leading indicator of loan performance, which demonstrates the importance of the link between real economy demand and loan impairment. Results also reveal that the level of outstanding credit in a sector cannot explain current loan impairment.

Santiago Carbo-Valverde and colleagues, on their firm-level panel data study on over 40,000 Spanish SMEs from 1994 to 2008, in a disequilibrium model framework revealed that financially constrained firms are more dependent on trade credit in making their investment decisions; financial crisis was associated with a credit crunch that affected the SME sector by increasing the number of credit-constrained firms [Carbo-Valverde S. et al., 2012]. The study concludes that trade creditors play a role in the SME sector as an alternative source of short-term financing and this role becomes more important during a credit crunch. Furthermore, Daniel and Gloria K.Q. Agyapong together with Kwabena N. Darfor empirically investigated the criteria for assessing small and medium enterprises' borrowers in Ghana [Agyapong D. et al., 2011]. The study focused on developing insight into the decision-making process which lenders employ in granting loans to SME borrowers. Questionnaires were employed to collect data from the selected bank branch managers of conventional banks, rural banks, and savings and loans companies. The study revealed that, when loan managers are deciding on whether to accept or reject an SME loan application, the intended purpose of loan, repayment of previous loan, repayment schedule, type of business activity, size of loan relative to size of business and availability of collateral ranked highest on their criteria list. In addition, the study established that curricula vitae of clients, government guarantee of loans, charges on assets and gearing ranked lowest on the criteria list in terms of importance. The study revealed that lenders take particular interest in risk when dealing with MSMEs. Anh $\mathrm{H}$. Nguyen explored the use of soft and hard information for bank lending decisions to small and medium enterprises in the country of Vietnam [Nguyen A.H., 2014]. The study aimed at investigating to what extent different types of information were used for loan approval, whether the two types of information were used in a complementary manner, and what factors determined the banks' lending decisions. Descriptive statistics was used for overall 
assessment; principal component analysis and confirmatory factor analysis, to establish and test the scales; and logistic regression, to examine determinants of lending decisions. The study findings indicated that, although collateral based lending is the most widespread method and could substitute for other lending technologies, usually a combination of lending information types is utilized in the decision-making process. This suggests that both complementarity and substitutability were found in the use of the various information types by Vietnamese banks for such decision-making.

Opuodho G. Omondi investigated the "effects of inflation on commercial banks' lending: a case of Kenya Commercial Bank Limited" [Omondi O.G., 2014]. The study adopted both descriptive research design with target population comprising of $450 \mathrm{KCB}$ employees from both management and non-management staff spread in all the 15 branches within Nairobi County and secondary data on inflation rates, new volume of lending to creditors, loan default volumes and bank lending rates. Primary data were analyzed using descriptive statistics, whereas secondary data were analyzed using inferential statistics through SPSS. The findings indicate that a rise in inflation rate contributes to an increase in the banks' lending rate, as this may be attributed to the fact that a rise in inflation leads to a fall in the purchasing power of money - thus, the banks demand a higher lending rate to cover seemingly riskier credit. Again, Collins O. Kwaning and others examined the difficulties that MSMEs face in accessing loan, difficulties that financial institutions face in lending to MSMEs, and the impact of loan on the profitability of MSMEs [Kwaning C.O., 2015]. Questionnaires were administered to MSMEs, and credit officers in the selected banks were interviewed. The following major findings came to the fore: interest rate on loan to the MSMEs is extremely high; repayment periods on loans to MSMEs are too short, making it very difficult to embark on any developmental or expansion projects; and most MSMEs do not understand the terms and conditions as well as are oblivious of the interpretation of the percentage charged on the loans. The study also found out that small business owners normally give false information when accessing loans from financial institutions. The study suggested that government should institute some form of tax incentives to financial institutions involved in SME lending and formulate regulatory laws to help loans recovery. According to its insights, SME associations must be established to unite them and serve as guarantors whenever loans are accessed.

In sum, it can be seen from the majority of the empirical works reviewed above that they support the transaction money demand theory and thus justify it as the underpinning theory for this research paper.

However, unlike previous studies reviewed (see, for instance [Alper K. et. al., 2014]), this research seeks to empirically examine whether there is a positive, negative or non-existent relationship between liquidity or interest rate on loans and the volume of loans extended to MSMEs. This work goes beyond the above to track and estimate the channels through which CRR impulses impact lending to SMEs in Nigeria. To achieve this, we adopt the VAR methodology as proposed by Christopher A. Sims [Sims C.A., 1980] and applied by studies on the effects of CRR on banks' lending in various countries (Nigeria, for instance, see [Olokoyo F.O., 2011], and for foreign studies see [Glocker C., Towbin P., 2012; Noss J., Toffano P., 2014]). The present study differs from past attempts by modifying the typical reduced form VAR model to link the interest rate channel and the liquidity channel as the two transmission channels through which impulses from CRR adjustments affect lending to SMEs.

\section{METHODOLOGY AND EMPIRICAL ANALYSIS}

\section{Methodology}

This model is specified to capture the objective aiming to empirically estimate the channels through which cash reserve ratio transmit to MSMEs' lending in Nigeria. 
The VAR representation is specified as:

$$
Y_{t}=\Phi Y_{t-1}+\theta X_{t}+\mu_{t}
$$

where $Y_{t}$ is the vector of endogenous variables, $X_{t}$ is the vector of exogenous variables, and $\mu_{t}$ is the residual vector. Furthermore, $\Phi$ is a matrix that includes all the coefficients describing the relationships among the endogenous variables, and $\theta$ is a matrix that includes all the coefficients describing the relationships among the endogenous and exogenous variables.

Equation 1 can further be transformed into a typical reduced form VAR as proposed by Sims [Sims C.A., 1980], as follows:

$$
Y_{t}=\mathrm{A}(L) Y_{t-1}+\varepsilon_{t}
$$

where $Y_{t}$ is the column vector of observations at time (t) on all variables and is known as the vector of endogenous variables. $L$ is the matrix of coefficients to be estimated, whereas the symbol $\varepsilon_{t}$ represents the column vector of random disturbances values called innovations, which may be contemporaneously correlated with each other and assumed to be non-autocorrelated over time. The above equation can be respecified in the following form:

$$
Y_{t}=A_{1} Y_{t-1}+A_{2} Y_{t-2}+A_{3} Y_{t-3}+\cdots+A_{k} Y_{t-p}+\varepsilon_{t}
$$

Here, each variable will be regressed on its own lags and the lags of the other variables in the model. This will provide a better insight into the dynamics of the system, which allows for feedback among the endogenous variables in the model. We further modify Equation 3 into the following two structural recursive forms to capture the two channels through which adjustments in CRR affect lending to MSMEs:

$$
\begin{aligned}
& {\left[\begin{array}{ccccc}
1 & 0 & 0 & 0 & 0 \\
\mathrm{a}_{12} & 1 & 0 & 0 & 0 \\
\mathrm{a}_{31} & \mathrm{a}_{32} & 1 & 0 & 0 \\
\mathrm{a}_{41} & \mathrm{a}_{42} & \mathrm{a}_{43} & 1 & 0 \\
\mathrm{a}_{51} & \mathrm{a}_{52} & \mathrm{a}_{53} & \mathrm{a}_{54} & 1
\end{array}\right]\left[\begin{array}{l}
\mathrm{CRR} \\
\mathrm{TBR} \\
\mathrm{SR} \\
\mathrm{LR} \\
\mathrm{SMEs}
\end{array}\right]=V(L)\left[\begin{array}{l}
\mathrm{CRR} \\
\mathrm{TBR} \\
\mathrm{SR} \\
\mathrm{LR} \\
\mathrm{SMEs}
\end{array}\right]+\left[\begin{array}{l}
\varepsilon_{C R R} \\
\varepsilon_{T B R} \\
\varepsilon_{S R} \\
\varepsilon_{L R} \\
\varepsilon_{S M E s}
\end{array}\right],} \\
& {\left[\begin{array}{ccccc}
1 & 0 & 0 & 0 & 0 \\
\mathrm{a}_{12} & 1 & 0 & 0 & 0 \\
\mathrm{a}_{31} & \mathrm{a}_{32} & 1 & 0 & 0 \\
\mathrm{a}_{41} & \mathrm{a}_{42} & \mathrm{a}_{43} & 1 & 0 \\
\mathrm{a}_{51} & \mathrm{a}_{52} & \mathrm{a}_{53} & \mathrm{a}_{54} & 1
\end{array}\right]\left[\begin{array}{l}
\mathrm{CRR} \\
\mathrm{LQR} \\
\mathrm{SR} \\
\mathrm{LR} \\
\mathrm{SMEs}
\end{array}\right]=V(L)\left[\begin{array}{l}
\mathrm{CRR} \\
\mathrm{LQR} \\
\mathrm{SR} \\
\mathrm{LR} \\
\mathrm{SMEs}
\end{array}\right]+\left[\begin{array}{l}
\varepsilon_{C R R} \\
\varepsilon_{T B R} \\
\varepsilon_{S R} \\
\varepsilon_{L R} \\
\varepsilon_{S M E s}
\end{array}\right],}
\end{aligned}
$$

where $\mathrm{CRR}=$ cash reserve ratio; $\mathrm{TBR}=$ Treasury bill rate; $\mathrm{LQR}=$ liquidity ratio; $\mathrm{SR}=$ saving rate; $L R=$ lending rate; SMES = credit to MSMEs. 
Equation 4 captures the interest rate channel, while Equation 5 is the liquidity channel through which CRR adjustment can influence credit to MSMEs. Each of the two channels is to track and examine the transmission mechanism of CRR adjustment impulses on credit to MSMEs. The interest rate channel assumes that CRR adjustment has implications on the opportunity cost of fund proxied by Treasury bill rate, savings/deposit rate, lending rate and credit to MSMEs. The liquidity channel assumes that CRR adjustment affects the liquidity condition, savings rate, lending rate and credit to the private sector. In other to evaluate the transmission channel and the impact of CRR adjustment on the selected monetary policy variables, after estimating the VAR model, impulse response function (IPF) and variance decomposition will be derived as well. The impulse response function examines the response of the dependent variable in a VAR model to shocks in the error term, hence:

$$
\begin{aligned}
& Y_{t}=a_{1}+a_{12} X_{t}+\theta_{11} Y_{t-1}+\theta_{12} X_{t-1}+\mu_{y t}, \\
& X_{t}=a_{2}+a_{21} Y_{t}+\theta_{21} Y_{t-1}+\theta_{22} X_{t-1}+\mu_{x t},
\end{aligned}
$$

where $Y_{t}$ and $X_{t}$ are stationary, and $\mu_{y t}$ and $\mu_{x t}$ are uncorrelated error terms.

\section{MODEL JUSTIFICATION}

According to Sims, if there is a true simultaneity among a set of variables, they should all be treated on an equal footing; there should not be any a priori distinction between endogenous and exogenous variables [Sims C.A., 1980]. The application of VAR in this study is to help forecast the impact of CRR adjustment on bank lending to MSMEs. The choice of this technique is based on the fact that VAR model helps to sought out the contemporaneous effects of a policy change on other variables and is also good for forecasting. The VAR methodology remains the major workhorse for estimating the effects of monetary and macroprudential policy transmission mechanism on macroeconomic and financial variables [Bernanke B.S., Blinder A.S., 1988].

\section{Empirical Analysis}

\section{Descriptive Statistics}

The descriptive statistics of the variables of study are analyzed below:

Table 1

\section{Statistical Analysis of Study Variables}

\begin{tabular}{|l|c|c|c|c|c|c|}
\hline & SME & CRR & LQR & LR & SR & TBR \\
\hline MEAN & 17.25395 & 0.756802 & 46.03359 & 17.96579 & 3.171797 & 10.37133 \\
\hline MEDIAN & 14.13688 & 0.755719 & 47.72500 & 16.92506 & 3.358750 & 10.60250 \\
\hline MAXIMUM & 38.38656 & 1.200000 & 63.20000 & 24.77083 & 5.155000 & 18.88000 \\
\hline MINIMUM & 11.80391 & 0.233675 & 30.40000 & 15.47983 & 1.410000 & 3.710000 \\
\hline SKEWNESS & 1.748924 & 0.062861 & -0.374392 & 1.816282 & -0.289677 & 0.282786 \\
\hline KURTOSIS & 4.630666 & 2.421554 & 2.487218 & 5.287243 & 2.335110 & 2.539360 \\
\hline JARQUE-BERA & 39.71738 & 0.934414 & 2.196324 & 49.13869 & 2.073949 & 1.418827 \\
\hline PROBABILITY & 0.00000 & 0.626750 & 0.333483 & 0.000000 & 0.354526 & 0.491933 \\
\hline OBSERVATIONS & 64 & 64 & 64 & 64 & 64 & 64 \\
\hline
\end{tabular}

Source: researchers' computation using EViews 9.0.

As shown by the table above, the data set for this study comprises of 64 quarterly observations ranging from 2001Q1 to 2017Q4. The table also shows that the average amount of credit to MSMEs in Nigeria quarterly is 17.25 billion. The average for cash reserve requirement 
is 0.756802 . The average liquidity ratio is $46 \%$. The average of lending interest rate is $17.9 \%$ while the average for saving interest rate is $3.17 \%$. It is worthy to note here that commercial banks obviously charge higher interest rates on their debtors but pay little or nothing to their creditors. The average rate of Treasury bill is $10.37 \%$ in 91 days (i.e. 3 months / a quarter of a year).

Furthermore, all the variables are right skewed, except LQR and SR which are negatively skewed. Kurtosis statistic of the variables shows that CRR, LQR, SR and TBR are platykurtic (short tailed or lower peak) while SME and LR are leptokurtic (long tailed or higher peak). Also, the probability of Jarque-Bera test shows that the residuals of SME and LR are not normally distributed while all other variables are normally distributed.

\section{Unit Root Test}

Null hypothesis: the series has a unit root.

Decision is made about the test result and conclusion to be drawn would be to reject the null hypothesis if the ADF t-statistic > the critical value in absolute terms; otherwise, we do not reject.

Table 2

\section{ADF Unit Root Test (Result)}

\begin{tabular}{|c|c|c|c|c|c|}
\hline VARIABLE & $\begin{array}{c}\text { ADF TEST } \\
\text { IN LEVEL }\end{array}$ & $\begin{array}{c}5 \% \text { CRITICAL } \\
\text { VALUE IN LEVEL }\end{array}$ & $\begin{array}{c}\text { ADF TEST } \\
\text { AT 1st D }\end{array}$ & $\begin{array}{c}5 \% \text { CRITICAL } \\
\text { VALUE AT 1st D }\end{array}$ & $\begin{array}{c}\text { INTEGRATION } \\
\text { ORDER }\end{array}$ \\
\hline SME & -2.997887 & -2.909206 & -2.731331 & -2.909206 & $\mathrm{I}(0)$ \\
\hline SR & -1.977469 & -2.908420 & -2.988941 & -2.908420 & $\mathrm{l}(1)$ \\
\hline TBR & -2.789098 & -2.908420 & -5.215970 & -2.910860 & $\mathrm{I}(1)$ \\
\hline LR & -3.312492 & -2.908420 & -2.287740 & -2.911730 & $\mathrm{l}(0)$ \\
\hline LQR & -3.199417 & -2.909206 & -2.400423 & -2.912631 & $\mathrm{I}(0)$ \\
\hline CRR & -2.102905 & -2.909206 & -4.629544 & -2.911730 & $\mathrm{l}(1)$ \\
\hline
\end{tabular}

Source: researchers' computation using EViews 9.0.

Table 2 above shows the stationarity of the time series. SME, LR and LQR are stationary in level while SR, TBR and CRR are made stationary at first difference. Having confirmed the stationarity of the series, we proceed to optimal lag length selection of the model using the Akaike information criterion (AIC).

Table 3

Optimal Lag Length Criterion

\begin{tabular}{|c|c|c|c|c|c|c|}
\hline Lag & LogL & LR & FPE & AIC & SC & HQ \\
\hline 0 & -205.4584 & N/A & 57.05834 & 22.79426 & 6.916854 & 6.895602 \\
\hline 1 & -120.1349 & 164.9589 & 3.432572 & 4.071162 & 4.140974 & 4.098469 \\
\hline 2 & -88.40193 & $60.29258^{*}$ & $1.232368^{*}$ & $3.046731^{*}$ & $3.151448^{*}$ & $3.087692^{*}$ \\
\hline 3 & -88.40164 & 0.000532 & 1.274273 & 3.080055 & 3.219678 & 3.134669 \\
\hline 4 & -88.37314 & 0.052257 & 1.316463 & 3.112438 & 3.286967 & 3.180706 \\
\hline
\end{tabular}

* Indicates lag order selected by the criterion.

Table 3 above shows the optimal lag length selection criteria. According to the results, LR, FPE, AIC, SC and HQ are all in favor of lag two (2), but this study will adopt AIC as its optimal lag length selection criterion.

\section{Johansen VAR Cointegration Test}

Cointegration occurs in time series variables when a long-run relationship exists amongst the variables or when there is stationarity in the error term in a regression model. The test involves 
finding the number of cointegrated vectors. In this step, the trace and maximum eigenvalue tests are seen in Tables 1 and 2. According to the cointegration test tables below, there are seven cointegration relationships between the time series. Table 3 shows the normalized cointegration vector on SME.

Table 4

Trace Cointegrated Rank Test

\begin{tabular}{|c|c|c|c|c|}
\hline Hypothesized No. of CE(s) & Eigenvalue & Trace Statistic & 0.05 Critical Value & Prob. $^{*}$ \\
\hline None * & 0.441724 & 125.3614 & 95.75366 & 0.0001 \\
\hline At most 1 * & 0.356816 & 89.80433 & 69.81889 & 0.0006 \\
\hline At most 2 * & 0.335997 & 62.88352 & 47.85613 & 0.0011 \\
\hline At most 3 * & 0.290514 & 37.90598 & 29.79707 & 0.0047 \\
\hline At most 4 * & 0.193485 & 16.96991 & 15.49471 & 0.0298 \\
\hline At most 5 * & 0.061209 & 3.852876 & 3.841466 & 0.0497 \\
\hline
\end{tabular}

Table 5

Maximum Eigenvalue Cointegration Rank Test

\begin{tabular}{|c|c|c|c|c|}
\hline Hypothesized No. of CE(s) & Eigenvalue & Max-Eigen Statistic & 0.05 Critical Value & Prob* \\
\hline None & 0.441724 & 35.55703 & 40.07757 & 0.1481 \\
\hline At most 1 & 0.356816 & 26.92081 & 33.87687 & 0.2676 \\
\hline At most 2 & 0.335997 & 24.97754 & 27.58434 & 0.1040 \\
\hline At most 3 & 0.290514 & 20.93607 & 21.13162 & 0.0532 \\
\hline At most 4 & 0.193485 & 13.11703 & 14.26460 & 0.0753 \\
\hline At most 5 * & 0.061209 & 3.852876 & 3.841466 & 0.0497 \\
\hline
\end{tabular}

Note: Trace and max-eigenvalue tests indicate 6 and one cointegrating equation at the 0.05 level, while * denotes rejection of the hypothesis at the 0.05 level.

Table 6

The Johansen Normalized Cointegrating Equation

\begin{tabular}{|l|c|c|c|c|c|c|}
\hline \multicolumn{1}{|c|}{ Variable } & SME & CRR & LQR & SR & TBR & LR \\
\hline Coefficient & 1.000000 & -11.56915 & 0.223372 & 4.953052 & 4.136745 & -7.159831 \\
\hline Stand. Error & & 6.49490 & 0.19989 & 1.77200 & 0.64713 & 1.08547 \\
\hline t-stat & & -1.7812668 & 1.1174746 & 2.7951761 & 6.3924482 & -6.5960653 \\
\hline
\end{tabular}

The long-run equilibrium equation showing the cointegration relationship between the variables is shown below.

$$
\mathrm{SME}=11.56915 \mathrm{crr}-0.223372 \mathrm{lqr}-4.953052 \mathrm{sr}-4.136745 \mathrm{tbr}+7.159831 \mathrm{lr} .
$$

The normalized equation indicates that there is a positive long-term relationship between CRR, LR and SME, while there is a negative long-term relationship between LQR, SR, TBR and SME at 95\% level of confidence, on average, ceteris paribus.

Conclusion: the null hypothesis of no cointegration is rejected against the alternative of a cointegrating relationship in the model. Therefore, we proceed to the estimation of the vector error correction model (VECM).

The Vector Error Correction Model (Result)

Table 7

\begin{tabular}{|l|c|c|c|c|c|c|}
\hline Error Correction: & $\mathrm{D}(\mathrm{SME})$ & $\mathrm{D}(\mathrm{CRR})$ & $\mathrm{D}(\mathrm{LQR})$ & $\mathrm{D}(\mathrm{SR})$ & $\mathrm{D}(\mathrm{TBR})$ & $\mathrm{D}(\mathrm{LR})$ \\
\hline CointEq1 & -0.025797 & -0.002426 & -0.025993 & 0.002478 & -0.048290 & 0.018096 \\
\hline $\mathrm{D}(\mathrm{SME}(-1))$ & 0.740998 & 0.003487 & -0.058461 & -0.005245 & 0.079530 & -0.040187 \\
\hline
\end{tabular}




\begin{tabular}{|l|c|c|c|c|c|c|}
\hline Error Correction: & $\mathrm{D}(\mathrm{SME})$ & $\mathrm{D}(\mathrm{CRR})$ & $\mathrm{D}(\mathrm{LQR})$ & $\mathrm{D}(\mathrm{SR})$ & $\mathrm{D}(\mathrm{TBR})$ & $\mathrm{D}(\mathrm{LR})$ \\
\hline $\mathrm{D}(\mathrm{CRR}(-1))$ & 2.612145 & 0.693003 & -3.961098 & 0.400651 & 0.158402 & 1.259808 \\
\hline $\mathrm{D}(\mathrm{LQR}(-1))$ & 0.037565 & 0.001300 & 0.732362 & 0.004663 & 0.028165 & -0.005964 \\
\hline $\mathrm{D}(\mathrm{SR}(-1))$ & -0.154174 & 0.050428 & 0.714442 & 0.773975 & 0.881846 & -0.204712 \\
\hline $\mathrm{D}(\mathrm{TBR}(-1))$ & 0.078575 & -0.003548 & 0.259457 & -0.002715 & 0.642368 & -0.037135 \\
\hline $\mathrm{D}(\mathrm{LR}(-1))$ & -0.449269 & 0.002400 & -0.092310 & 0.014728 & 0.023032 & 0.767855 \\
\hline $\mathrm{C}$ & -0.044648 & 0.002727 & 0.028641 & -0.003445 & -0.015621 & -0.041791 \\
\hline R-squared & 0.645925 & 0.567673 & 0.555848 & 0.679799 & 0.620321 & 0.604613 \\
\hline
\end{tabular}

The error correction term indicates that the previous period's deviation from the long-run equilibrium is corrected in the current period at an adjustment speed of $2.57 \%$. For the CRR, a percentage increase in CRR is associated with $2.6 \%$ increase in SME on average, ceteris paribus, in the short run. Also, a percentage positive change in LQR leads to $3.7 \%$ increase in SME on average, ceteris paribus, in the short run. On the contrary, $1 \%$ increase in SR is associated with $15.4 \%$ decline in SME on average, ceteris paribus, in the short run. However, a percentage increase in TBR would lead to $7.8 \%$ increase in SME on average, ceteris paribus, on the short run, while $1 \%$ increase in LR is associated with $44.9 \%$ decrease in SME on average, ceteris paribus, in the short run.

\section{Diagnostic Tests}

In order to check for the efficiency of the VECM model and also ensure that it is in line with the white noise assumption, residual based tests such as serial correlation LM Test for autocorrelation, the Jarque-Bera test for normality and the Breusch-Pagan-Godfrey test for heteroskedasticity were conducted.

\section{Test for Serial Correlation}

VEC Residual Serial Correlation LM Tests

Table 8

\begin{tabular}{|c|c|c|}
\hline Lags & LM-Stat & Prob. \\
\hline 1 & 14.01535 & 0.9996 \\
\hline 2 & 3.623348 & 1.0000 \\
\hline
\end{tabular}

Given that VECM remains a system model, the serial correlation LM test was employed to test for residual autocorrelation among the variables of the study, as shown in Table 8 above. To reject the null hypothesis, the probability of the observed LM statistics must be greater than $5 \%$. The result depicts a rejection of the null hypothesis for both lags, implying the inexistence of serial correlation among all the variables in the VAR model.

\section{Normality Test}

Table 9

\section{Multivariate Normality Test}

\begin{tabular}{|c|c|c|c|}
\hline Component & Jarque-Bera & df & Prob. \\
\hline 1 & 414.9456 & 2 & 0.3996 \\
\hline 2 & 279.7213 & 2 & 0.1825 \\
\hline 3 & 777.0545 & 2 & 0.0977 \\
\hline 4 & 131.1373 & 2 & 0.2718 \\
\hline 5 & 45.43303 & 2 & 0.3521 \\
\hline 6 & 0.736979 & 2 & 0.5710 \\
\hline Joint & $1,649.029$ & 12 & 0.3664 \\
\hline
\end{tabular}


Table 9 shows the multivariate normality test result for the VECM model depicting the JarqueBera. It is often seen as pointless to report the results of Skewness and Kurtosis in VECM since Jarque-Bera is the summary of both results, and thus only Jarque-Bera is reported in this study. To reject the null hypothesis that the residuals in the VECM are normally distributed, the probability of the joint Jarque-Bera statistics must be greater than $5 \%$. The result shows that all the six equations in the model are normally distributed and, more importantly, jointly normally distributed in the overall model given a Jarque-Bera statistic of $36.6 \%$, which is clearly greater than $5 \%$.

\section{Heteroskedasticity Test}

Table 10

VEC Residual Heteroskedasticity Tests: No Cross Terms (Only Levels and Squares)

\begin{tabular}{|c|c|c|}
\hline Joint Test: & & \\
\hline Chi-sq & df & Prob. \\
\hline 438.0907 & 294 & 0.0947 \\
\hline
\end{tabular}

The result in Table 10 above shows that the residuals are not heteroscedastic; thus, they are homoscedastic given a probability value of $9.47 \%$, which is greater than $5 \%$ level. Thus we proceed to VECM impulse response.

\section{VECM VARIANCE DECOMPOSITION}

Objective: to determine the channels through which cash reserve ratio transmits to MSMEs lending in Nigeria. Put differently, amongst channels of transmission such as LR, LQR, and TBR, which has the strongest impact on SME?

Table 11

\section{Variance Decomposition}

Variance Decomposition of SME:

\begin{tabular}{|c|c|c|c|c|c|c|c|}
\hline Period & S.E. & SME & CRR & LQR & TBR & SR & LR \\
\hline 1 & 1.138170 & 100.0000 & 0.000000 & 0.000000 & 0.000000 & 0.000000 & 0.000000 \\
\hline 2 & 2.284083 & 98.94300 & 0.666765 & 0.054803 & 0.003914 & 0.004680 & 0.326836 \\
\hline 3 & 3.522436 & 97.06510 & 1.717192 & 0.164994 & 0.008324 & 0.037612 & 1.006773 \\
\hline 4 & 4.815319 & 95.11155 & 2.681129 & 0.316004 & 0.006850 & 0.111392 & 1.773072 \\
\hline 5 & 6.122174 & 93.43787 & 3.405775 & 0.505394 & 0.004751 & 0.215766 & 2.430444 \\
\hline
\end{tabular}

Variance Decomposition of CRR:

\begin{tabular}{|c|c|c|c|c|c|c|c|}
\hline Period & S.E. & SME & CRR & LQR & TBR & SR & LR \\
\hline 1 & 0.036954 & 0.003602 & 99.99640 & 0.000000 & 0.000000 & 0.000000 & 0.000000 \\
\hline 2 & 0.069460 & 0.177777 & 98.93533 & 0.026592 & 0.476085 & 0.080933 & 0.303281 \\
\hline 3 & 0.100643 & 0.255147 & 96.30157 & 0.116680 & 1.772135 & 0.149252 & 1.405220 \\
\hline 4 & 0.130655 & 0.168948 & 92.33150 & 0.250844 & 3.659708 & 0.147235 & 3.441769 \\
\hline 5 & 0.160106 & 0.174132 & 87.48830 & 0.377201 & 5.688268 & 0.106556 & 6.165547 \\
\hline
\end{tabular}

Variance Decomposition of LQR:

\begin{tabular}{|c|c|c|c|c|c|c|c|}
\hline Period & S.E. & SME & CRR & LQR & TBR & SR & LR \\
\hline 1 & 1.636179 & 3.067454 & 8.412138 & 88.52041 & 0.000000 & 0.000000 & 0.000000 \\
\hline 2 & 3.212409 & 4.160468 & 6.900439 & 88.87998 & 0.044324 & 0.012322 & 0.002464 \\
\hline 3 & 4.795106 & 5.396314 & 5.573841 & 88.86352 & 0.107552 & 0.028995 & 0.029776 \\
\hline 4 & 6.335450 & 6.831204 & 4.454268 & 88.39739 & 0.162381 & 0.037803 & 0.116950 \\
\hline 5 & 7.819374 & 8.471180 & 3.547420 & 87.45271 & 0.205017 & 0.036267 & 0.287404 \\
\hline
\end{tabular}


Variance Decomposition of TBR:

\begin{tabular}{|c|c|c|c|c|c|c|c|}
\hline Period & S.E. & SME & CRR & LQR & TBR & SR & LR \\
\hline 1 & 0.544549 & 2.229488 & 20.07566 & 7.539185 & 70.15567 & 0.000000 & 0.000000 \\
\hline 2 & 0.973353 & 1.155206 & 18.97679 & 7.677953 & 71.54906 & 0.110470 & 0.530524 \\
\hline 3 & 1.333122 & 0.862564 & 17.97186 & 7.463787 & 70.65298 & 0.203201 & 2.845602 \\
\hline 4 & 1.644727 & 1.155342 & 16.72880 & 6.979158 & 67.03037 & 0.184602 & 7.921726 \\
\hline 5 & 1.948797 & 2.412232 & 15.05854 & 6.293647 & 60.58866 & 0.132841 & 15.51408 \\
\hline
\end{tabular}

Variance Decomposition of SR:

\begin{tabular}{|c|c|c|c|c|c|c|c|}
\hline Period & S.E. & SME & CRR & LQR & TBR & SR & LR \\
\hline 1 & 0.086449 & 4.859089 & 13.45841 & 23.28274 & 4.892075 & 53.50768 & 0.000000 \\
\hline 2 & 0.167436 & 4.225869 & 8.863127 & 22.44791 & 4.721907 & 59.74094 & 0.000247 \\
\hline 3 & 0.249854 & 3.892115 & 5.630747 & 21.15248 & 4.389406 & 64.93084 & 0.004404 \\
\hline 4 & 0.332816 & 3.743125 & 3.526672 & 19.54911 & 4.033229 & 69.13500 & 0.012862 \\
\hline 5 & 0.415982 & 3.689069 & 2.275987 & 17.81480 & 3.735070 & 72.46620 & 0.018875 \\
\hline
\end{tabular}

Variance Decomposition of LR:

\begin{tabular}{|c|c|c|c|c|c|c|c|}
\hline Period & S.E. & SME & CRR & LQR & TBR & SR & LR \\
\hline 1 & 0.250581 & 1.080189 & 4.784577 & 0.634282 & 20.43364 & 1.380977 & 71.68633 \\
\hline 2 & 0.483784 & 0.360684 & 1.942860 & 0.723458 & 23.56726 & 1.733636 & 71.67210 \\
\hline 3 & 0.711158 & 0.167261 & 0.919441 & 0.900368 & 27.37409 & 1.740682 & 68.89816 \\
\hline 4 & 0.925233 & 0.108173 & 1.148337 & 1.115726 & 31.50701 & 1.493547 & 64.62721 \\
\hline 5 & 1.125277 & 0.186647 & 2.188276 & 1.310598 & 35.46086 & 1.143977 & 59.70964 \\
\hline
\end{tabular}

Note: cholesky decomposition of SME, CRR, LQR, TBR, SR, LR.

Source: result output from EViews estimations.

Table 11 above shows the variance decomposition of all the endogenous variables in the VECM models. Variance decomposition of the forecast error gives the percentage of unexpected variation in each variable which is produced by shocks from other variables. It also indicates the relative impact that a variable has on another variable. It explains the relative significance of each random shock of the variables in the model. The above is used in this research to explain the magnitude of change that SR, LR, LQR, and TBR impact on SME as channels of transmission from CRR to SME in both the short run and the long run. In this study, the short run is represented by first to second year periods while the long run is captured by third to fifth year periods.

In the variance decomposition of SME, own shock constitutes the entire source of variation in the first period; it declined gradually and was at $93.4 \%$ in the fifth period. Beside own shocks, shocks in the CRR, LQR, TBR, SR and LR were seen to have impacted the SME mostly causing about $3.4 \%, 0.5 \%, 0.0 \%, 0.2 \%$ and $2.4 \%$ variation respectively in the fifth period. Thus, SME has a strong influence on itself in both the short run and the long run. This is also in line with the result from VECM, where SME accounts for about $74 \%$ change with 6.25 t-statistic in the model.

Another interesting discovery is the insignificant impact of CRR on variations in SME in the short run, though it increased from $0.3 \%$ in the first period to $17.4 \%$ in the fifth period. This impact is insignificant because its t-statistic is far less than two in the VECM. This result is in line with Adedayo and Ayodeji, who estimated the effects of CRR on banks' lending to the MSMEs in Nigeria, and their results show that there is no significant relationship between CRR and the volume of loans to MSMEs [Adedayo O.F., Ayodeji E.A., 2015]. However, CRR makes further significant impact on SME through LQR and LR. According to the variance decomposition of SME, in the first period, LQR accounts for only 5.4\% variations in SME, but in the fifth period this increased to $50.5 \%$. At the same time the LR also increased from $0.33 \%$ 
in the first period to $2.43 \%$ in the fifth period. This confirms that CRR impacts on SME through LQR and LR as its transmission channels.

\section{SUMMARY, POLICY RECOMMENDATIONS AND CONCLUSION}

For this study, VAR model was adopted to determine the channels through which cash reserve ratio transmits to MSMEs lending in Nigeria. The data used were quarterly data sourced from the CBN covering the period from 2001 to 2017. Johansen Cointegration test was used to confirm the presence of cointegration among the variables of study and Augmented Dickey Fuller (ADF) was used to confirm their order of integration. The error correction term indicates that the previous period's deviation from the long-run equilibrium is corrected in the current period at an adjustment speed of $2.57 \%$. For the CRR, a percentage increase in CRR is associated with $2.6 \%$ increase in SME on average, ceteris paribus, in the short run. Also, a percentage positive change in LQR leads to 3.7\% increase in SME on average, ceteris paribus, in the short run. On the contrary, $1 \%$ increase in SR is associated with $15.4 \%$ decline in SME on average, ceteris paribus, in the short run. However, a percentage increase in TBR would lead to $7.8 \%$ increase in SME on average, ceteris paribus, on the short run, while 1\% increase in LR is associated with $44.9 \%$ decrease in SME on average, ceteris paribus, in the short run. According to the variance decomposition of SME, in the first period, LQR accounts for only $5.4 \%$ variations in SME, but in the fifth period this increased to $50.5 \%$. The LR also increased from $0.33 \%$ in the first period to $2.43 \%$ in the fifth period. This confirms that CRR impacts on SME through LQR and LR as its transmission channels in the long run.

The residual diagnostic tests conducted such as residual serial correlation LM tests, normality test, and heteroscedasticity confirmed that the model specified is fine and reliable for forecasting.

\section{Policy Recommendations}

The study recommends that the Central Bank reduce its cash reserve ratio in order to increase commercial banks' liquidity. As the commercial banks' liquidity rises, they should also reduce their lending interest rate to increase access to credit by MSMEs. Banks and the government should not concentrate on the use of cash reserve ratio only in a bid to increase credit to SMEs in Nigeria. There is need to regulate the commercial banks' asset base to increase their liquidity ratio so as to increase access to credit by SMEs. Again, government should, as a matter of necessity, appropriate and monitor the judicious disbursement of interest-free loans/credit to SMEs in Nigeria as these would boost productivity and the Nigerian economy in the long run.

\section{Conclusion}

This study examines the channels of transmission through which cash reserve ratio impacts on credit to micro-, small and medium-sized enterprises (MSMEs). A vector error correction model was used to capture the objective. Quarterly data ranging from 2001 to 2017 were also utilized in the analysis. The study discovered that cash reserve ratio indirectly impacts credit to MSMEs through liquidity ratio and lending interest rate as its channels of transmission. It is worthy to note that, as liquidity ratio has a positive significant impact on credit to MSMEs, lending interest rate has a negative but significant impact on credit to MSMEs. 


\section{References}

Adedayo O.E., Ayodeji E.A. (2015). Cash Reserve Requirement and Lending Behaviour of Banks to Small and Medium Scale Enterprises in Nigeria. International Journal of Banking, Finance, Management \& Development Studies, 3 (1), pp. 23-34.

Agyapong D., Agyapong G.K.Q., Darfor K.N. (2011). Criteria for Assessing Small and Medium Enterprises' Borrowers in Ghana. International Business Research, 4 (4), pp. 132-138.

Ajayi F., Atanda A. (2012). Monetary policy and bank performance in Nigeria: A two-step cointegration approach. African Journal of Scientific Research, 9(1), pp. 34-47.

Alper K., Binici M., Demiralp S. et al. (2014). Reserve Requirements, Liquidity Risk and Credit Growth. CBRT Working Paper, 1424.

Anigbogu T.U., Okoli I.M., Nwakoby, N.P. (2015). Financial Intermediaries and Small and Medium Enterprises Perfromance in Nigeria (An Aggregated Analysis: 1980-2013). European Scientific Journal, 11(28), pp. 257-272.

Ayeni-Agbaje A.R., Osho A.E. (2015). Commercial Banks Role in Financing Small Scale Industries in Nigeria (A Study of First Bank Plc Ado Ekiti State). International Journal of Innovative Finance and Economics Research, 4(2), pp. 8-15.

Becker M.C., Knudsen T. (2002). Schumpeter 1911: Farsighted visions on economic development. American Journal of Economics and Sociology, 61(2), pp. 387-403.

Bemanke B.S. and Blinder A.S. (1988). Credit, Money and Aggregate Demand. American Economic Review, 78, pp. 435-439.

Carbo-Valverde S., Rodriguez-Fernandez F., Udell G.F. (2016). Trade Credit, the Financial Crisis, and Firm Access to Finance. Journal of Money, Credit and Banking, 48(1), pp. 113-143. DOI: 10.1111/jmcb.12292.

CBN (2005). Central Bank of Nigeria Statistical Bulletin and Reports, Abuja.

CBN (2000). Central Bank of Nigeria Statistical Bulletin, Abuja.

Chinanuife E., Madueme S.I., Orji A., and Anthony-Orji O.I. (2019). Empirical Determination of the Causal Link Between Private Sector Credit and Manufacturing Output in Nigeria. Journal of Advanced Research in Management, vol. X, Summer, 1(19), pp. 44-51. DOI: 10.14505/jarm.v10.1(19).05. Available online: https://journals.aserspublishing. eu/jarm/article/view/3774.

Ben-Caleb E., Adeyemi K.S. and lyoha F. (2014). The Impact of Budget Reforms on the Quality of Budget Management in Nigeria. Journal of Accounting and Auditing: Research and Practice, Article ID 207739. DOI: $10.5171 / 2014.207739$

Gerschenkron A. (1962). Economic backwardness in historical perspective. The Political Economy Reader: Markets as Institutions, pp. 211-228.

Glocker C., Towbin P. (2012). Reserve Requirements for Price and Financial Stability: When Are They Effective? International Journal of Central Banking, 8(1), pp. 66-71.

Imoughele L.E., Ismaila M. (2014). The Impact of Commercial Bank Credit on the Growth of Micro, Small and Medium Scale Enterprises: An Econometric Evidence from Nigeria (1986-2012). Journal of Educational Policy and Entrepreneurial Research (JEPER), 1(2), pp. 251-261.

Iniodu P.U., Udomesict C.U. (2004). Commercial Banking System Efficiency and Financing Small Scale Enterprises in the 21St Century. In Leading Issues in Macroeconomic Management and Development. Abdul-Ganiyu Garba, Festus Egwaikhide, and Adeola Adenikinju (eds.). Daily Graphics Nigeria limited, Ibadan, pp. 161-183.

Kwaning C.O., Nyantakyi K., Kyereh B. (2015). The Challenges behind MSMEs' Access to Debts Financing in the Ghanaian Financial Market. International Journal of Small Business and Entrepreneurship Research, 3(2), pp. 16-30.

Lawless M., McCann F. (2011). Credit Access for Small and Medium Firms: Survey Evidence for Ireland. Research Technical Papers 11/RT/11, Central Bank of Ireland.

Levine R. (1997). Financial development and economic growth: views and agenda. Journal of Economic Literature, 35(2), pp. 688-726.

Mbanasor J.A., Okeke A.M., Nto P.O. (2015). Determinants of Investment Capacity Among Yam Production Entrepreneurs in Benue State, Nigeria. Journal of Poverty, Investment and Development, 16(4), pp. 20-35.

McKinnon R.I. (1989). Financial liberalization and economic development: A reassessment of interest-rate policies in Asia and Latin America. Oxford Review of Economic Policy, 5(4), pp. 29-54.

Ndugbu M.O., Okere P.A. (2015). Monetary Policy and the Performance of Deposit Money Banks - the Nigerian Experience. European Journal of Business and Management, 7(17), pp. 65-72.

Nguyen A.H. (2014). Vietnamese banks' decision making in lending to small \& medium enterprises (SMEs) based on soft and hard information, Ritsumeikan Journal of Asia Pacific Studies, 33, pp. 79-94.

Noss J., Toffano C.P. (2016). Estimating the impact of changes in aggregate bank capital requirements during an upswing. Journal of Banking \& Finance, 63(C), pp. 15-27.

Nwosu E.O., Orji A., Urama N.E. et al. (2020). Social Capital, Credit Access and Household Nonfarm Enterprises in Nigeria: A New Empirical Evidence. Forum for Social Economics. DOI: 10.1080/07360932.2020.1825983.

Nwosu E.O., Orji A. (2016). Access to Formal Credit and Enterprise Performance In Nigeria: A Gender Perspective. Argumenta Oeconomica, 36 (1), pp. 191-224. Available online: http://www.dbc.wroc.pl/dlibra/doccontent?id=32150.

Ogechukwu O.L., Akinlo A.E., Goldman G.A. (2015). Financial Schemes to Boost Small and Medium Sized Enterprises Sources of Finance by the Nigerian Government: A Commentary. Banks and Bank Systems, 10(3), pp. 49-60. 
Olokoyo F.O. (2011). Determinants of Commercial Banks' Lending Behavior in Nigeria. International Journal of Financial Research, 2(2), 61-72. DOI: 10.5430/ijfr.v2n2p61.

Omika M. (2014). Repositioning Commercial Banks to Enhance the Productive Capacities of Micro, Small and Medium Scale Enterprises (MSMEs) for Economic Growth of Developing Nations: A Focus on Nigeria. International Journal of Public Administration and Management Research (IJPAMR), 2(2).

Omondi O.G. (2014). Effects of Inflation on Commercial Banks' Lending: A Case of Kenya Commercial Bank Limited (Doctoral Dissertation, United States International University Africa, Chandaria School of Business).

Orji A., Ogbuabor J.E., Ugwu E.C., Anthony-Orji O.I. (2019). Cash Reserve Requirement and Credit to SMEs in Nigeria: An ARDL Bounds Test Approach. Journal of Asian Business Strategy. 9(1), pp. 10-28. DOI: 10.18488/ journal.1006.2019.91.10.28. Available online: http://www.aessweb.com/pdf-files/JABS-2019-9(1)-10-28.pdf.

Orji A., Anthony-Orji O.I., Mba P.N. (2015). Financial Liberalization and Output Growth in Nigeria: Empirical Evidence from Credit Channel. International Journal of Economics and Financial Issues, 5 (1), pp. $297-311$. Available at: http://www.econjournals.com/index.php/ijefi/article/view/1099/pdf.

Orji A. (2012). Bank Savings and Bank Credits in Nigeria: Determinants and Impact on Economic Growth. International Journal of Economics and Financial Issues, 2(3), pp. 357-372. Available at: http://econjournals.com/ index.php/ijefi/article/view/67.

Patrick H.T. (1966). Financial development and economic growth in underdeveloped countries. Economic development and Cultural change, 14(2), pp. 174-189.

Rahji M.A.Y., Apata T.G.G. (2008). Understanding the Credit Supply Decisions of Banks Under the Small and Medium Enterprises Equity Investment Scheme (SMEEIS) in Nigeria (July, 10 2008). Available at: http://dx.doi. org/10.2139/ssrn.1157781.

Sacerdoti E. (2005). Access to Bank Credit in Sub-Saharan Africa: Key Issues and Reform Strategies. IMF Working Paper 05/166, International Monetary Fund.

Safiriyu A.M., Njogo B.O. (2012). Impact of Micro, Small and Medium Scale Enterprises in Lagos State. Kuwait Chapter of Arabian Journal of Business and Management Review, 11(1), p. 107.

Sims C.A. (1980). Macroeconomics and Reality. Econometrica, 48(1), pp. 1-48.

Uzonwanne M.C. (2015). Deposit Money Banks and Financing of Micro, Small and Medium Scale Enterprises in Nigeria. Journal of Economics and Sustainable Development, 6(8), pp. 185-95.

Article submitted October 4, 2021

Approved after reviewing December 20, 2021

Accepted for publication February 4, 2022

https://doi.org/10.31107/2075-1990-2022-1-71-88

\section{Коэффициент наличных резервов и кредитование микро-, малых и средних предприятий в развивающихся странах. Анализ трансмиссионных каналов с использованием данных по Нигерии}

\section{Энтони Орджи}

E-mail: anthony.orji@unn.edu.ng

Университет Нигерии, факультет экономики, г. Нсукка 400001, Федеративная Республика Нигерия

Ажонатан Э. Огбуабор

E-mail: jonathan.ogbuabor@unn.edu.ng

Университет Нигерии, факультет экономики, г. Нсукка 400001, Федеративная Республика Нигерия Кристиан Э. Угву

E-mail: ugwuchristian68@yahoo.com

Университет Нигерии, факультет экономики, г. Нсукка 400001, Федеративная Республика Нигерия

Онинье И. Энтони-Орджи

E-mail: onyinye.anthony-orji@unn.edu.ng (автор-корреспондент)

Университет Нигерии, факультет экономики, г. Нсукка 400001, Федеративная Республика Нигерия

Аинда К. Нвуфо

E-mail: lynda.nwufo@unn.edu.ng

Университет Нигерии, факультет экономики, г. Нсукка 400001, Федеративная Республика Нигерия 


\section{Аннотация}

В этом исследовании рассматриваются трансмиссионные каналы, посредством которых коэффициент наличных резервов влияет на кредитование микро-, малых и средних преАприятий (ММСП). Аля этой цели была применена векторная модель коррекции ошибок. В анализе также использовались квартальные данные за период с 2001 по 2017 г. Исследование показало, что коэффициент наличных резервов косвенно влияет на кредитование ММСП через коэффициент миквидности и процентную ставку по кредитам в качестве трансмиссионных каналов. При этом коэффициент миквидности оказывает существенное положительное влияние на кредитование ММсП, тогАа как процентная ставка по кредиту оказывает существенное негативное влияние на кредитование ММСП. Таким образом, Аля повышения производительности экономики в развивающихся странах органам денежно-кредитного регулирования рекомендовано снизить коэффициент наличных резервов, чтобы повысить Аиквидность коммерческих банков. По мере роста АиквиАности коммерческих банков им также следует уменьшать процентные ставки по кредитам, чтобы расширить Аоступ к кредитам Аля ММСП. Правительствам следует предусматривать и контролировать предоставление в надлежащих объемах беспроцентных займов/кредитов ММСП через банки - прежде всего, банки развития.
\end{abstract}

Ключевые слова: коэффициент наличных резервов, кредитование, трансмиссионные каналы, микро-, малые и средние предприятия

JEL: E51, G21, L26

А^я цитирования: Orji A., Ogbuabor J.E., Ugwu C.E., Anthony-Orji O.I., Nwufo L.C. Cash Reserve Ratio and Credit to Micro-, Small and Medium-Sized Enterprises in Developing Economies. Analysis of Transmission Channels Using Nigerian Data. Financial Journal, 2022, vol. 14, no. 1, pp. 71-88. https://doi.org/10.31107/2075-1990-2022-1-71-88.

(C) Orji A., Ogbuabor J.E., Ugwu C.E., Anthony-Orji O.I., Nwufo L.C., 2022

Статья поступила в редакцию 04.10.2021

ОАобрена после рецензирования 20.12.2021

Принята к публикации 04.02.2022 